\title{
Trialogical Learning as a Theoretical Framework in the Digital Ecosystem of a Maker Community: a Case Study
}

Jesús Valverde-Berrocoso ${ }^{1}$, María Rosa Fernández-Sánchez ${ }^{2}$

1 Department of Education Sciences, Faculty of Teacher Training, University of Extremadura, Avda. de la Universidad s/n 10003-Cáceres, Spain, jevabe@unex.es

2 Department of Education Sciences, Faculty of Teacher Training, University of Extremadura, Avda. de la Universidad s/n 10003-Cáceres, Spain, rofersan@unex.es

Abstract. Digital media is transforming teaching-learning processes. It is necessary to understand the new ecologies of learning that are developing in technological ecosystems. In this article, a learning community is analysed from the perspective of «trialogical learning», and the components of the triad are identified: elements, interactions, and products. The case study offers the possibility of transferring this knowledge for the transformation of formal learning.

Keywords: trialogical learning approach, maker movement, Do It Yourself (DIY), case study, community of practice.

\section{Introduction}

To understand and analyse new learning ecologies, it is necessary to overcome the dichotomy that exists within the learning approach of the last 50 years and which can be synthesised into two epistemological metaphors. We have the metaphor of «acquisition» or "monologue» (inside the mind): knowledge as property or capacity of the individual mind and learning as a process of construction, acquisition, and formation of results which are visible in transference (the use and application of knowledge in new situations). This vision underscores computational models of the mind and knowledge, intending to stimulate ways in which the mind might operate with that knowledge. We also have the metaphor of «participation» or «dialogue» (between individual mediators): 
where learning is a process of participation in diverse cultural practices and manifested in a shared activity. The focus is found in activities («knowing») more than in results or outcomes («knowledge»). It is suggested that knowledge does not exist in the individual mind, save through the participation in cultural practices.

Current, more complex learning environments: distributed, connected, flexible and ubiquitous (Aguaded \& Cabero, 2014), require the incorporation of a new metaphor regarding «knowledge creation», i.e. a collective creation of knowledge, employing shared activity objects. This approach is known as «trialogical learning (Paavola et al., 2004; Paavola \& Hakkarainen, 2005; Hakkarainen, 2009; Muukkonen \& Lakkala, 2009; Paavola et al., 2011) and it is based on theories about knowledge creation within organizations (Nonaka \& Takeuchi, 1995), expanded learning (Engeström \& Sannino, 2010; Engeström, 2015) and knowledge construction (Bereiter, 2002). The principles shared by these theories are as follows (Paavola, Lipponen, \& Hakkarainen, 2004):

(1) The creation of knowledge is not linear but instead, an ambiguous process and one of «creative chaos». In consequence, there is conflict between: (i) a transmission of already elaborated knowledge, which «hides» the way in which new knowledge is generated; (ii) a «reactive» learning, in which activities are preconfigured, in opposition to «expanded» learning where one learns new forms of unanticipated activity; (iii) the goal of learning is not simply to «improve» our individual comprehension of some phenomenon or reality but rather, contribute to the development of new objects for culturally shareable knowledge.

(2) The creation of knowledge as a social process: New ideas and innovations emerge «between» people more than «inside» of people. The creation of knowledge is not primarily a matter of individual creation. It requires the reorganisation of practices by the whole community. Epistemological processes should be supported by social processes and vice versa.

(3) The role of individuals in the creation of knowledge: In these models, the individual has a fundamental part to play in new learning because: (i) he contributes his tacit knowledge; (ii) he questions existing practices to initiate a cycle of expanded knowledge; (iii) he makes an effort to resolve problems and develop a complex relationship with the objects of his learning.

(4) Going beyond propositional and conceptual knowledge: knowledge is always imbibed in practice, in contrast with mentalist tradition whereby «knowledge is in the mind».

(5) Interaction through shared objects: Interaction finds its place in the use of objects (e.g. technological devices, systems of activity or conceptual artifacts), not only among people. Neither individual initiatives, nor collective practices by themselves hold primary importance; what is crucial is the way in which they are directed and organised in function of the development of shared objects. 


\section{Trialogical Learning Approach (TLA)}

«Trialogical learning» is a co-evolution between investigators and the objects of their investigations. Such objects can be conceptual (questions, theories, designs), material (prototypes, concrete products), or representative of practices which lead to collective reflection or transformation. Learning is a process of innovative inquiry where the goal is to progressively refine the devices of knowledge and develop long-term processes for the extension of that knowledge within the community and its jurisdiction (Hakkarainen \& Paavola, 2009).

Trialogical learning is the result of interaction between individuals or groups that create «shared objects» (material or conceptual), characterized by being ambivalent knowledge holders (epistemological objects). This is because they are stable, i.e. they represent what is known at a particular moment and on the other hand, they are changeable and consequently, incomplete and open to subsequent developments that generate new knowledge (Malins et al., 2015).

Advancement in knowledge and creativity can be understood as a «trialogical activity», meaning an activity in which people working together are elaborating a shared object, whether it be an investigative problem, a theory, a plan, a design, a product or a practice (to be reflected upon or transformed).

Table 1

The Three Learning Metaphors: Monological-Adoption / Dialogical-Construction/ Trialogical-Creation

\begin{tabular}{|c|c|c|c|}
\hline & Monological & Dialogical & Trialogical \\
\hline Process & $\begin{array}{l}\text { Adoption of knowledge } \\
\text { based on mental repre- } \\
\text { sentations. }\end{array}$ & $\begin{array}{l}\text { Knowledge construction } \\
\text { using participation in } \\
\text { social communities, cog- } \\
\text { nitive enculturation and } \\
\text { socialization. }\end{array}$ & $\begin{array}{l}\text { Creation of new material and } \\
\text { conceptual artifacts for pro- } \\
\text { motion, discovery and delibe- } \\
\text { rate innovation of know- } \\
\text { ledge. }\end{array}$ \\
\hline $\begin{array}{l}\text { Theoretical } \\
\text { founda- } \\
\text { tions }\end{array}$ & $\begin{array}{l}\text { Cognitivism (Bruner } \\
\text { et al., 1956). Processing } \\
\text { Information (Miller, 1956). } \\
\text { Learning by Association } \\
\text { (Anderson, 1983). } \\
\text { Learning by Restructuring } \\
\text { (Ausubel et al., 1978). }\end{array}$ & $\begin{array}{l}\text { Situated and distributed } \\
\text { cognition (Brown et al., } \\
\text { 1989). Communities of } \\
\text { practice (Lave \& Wenger, } \\
\text { 1991). Social Epistemo- } \\
\text { logy (Fuller, 1991). }\end{array}$ & $\begin{array}{l}\text { Trialogical Learning (Paavo- } \\
\text { la \& Hakkarainen, 2005). } \\
\text { Know-ledge creating organi- } \\
\text { zations (Nonaka \& Takeuchi, } \\
\text { 1995). Expansive Learning } \\
\text { Theory (Engeström, 1987). } \\
\text { Education and mind in the } \\
\text { knowledge age (Bereiter, } \\
\text { 2002). }\end{array}$ \\
\hline $\begin{array}{l}\text { Units of } \\
\text { analysis }\end{array}$ & Individuals. & $\begin{array}{l}\text { Groups, communities, } \\
\text { networks and cultures. }\end{array}$ & $\begin{array}{l}\text { Individuals and groups } \\
\text { creating knowledge artifacts } \\
\text { within cultural contexts. }\end{array}$ \\
\hline
\end{tabular}

Source: Prepared by author. 
Trialogical objects are tangible, epistemic artifacts which participants are creating, sharing, and elaborating with frequency through Information and Communication Technologies. Epistemic artifacts are different products of knowledge derived from human activity: ideas, concepts, theories and models. These entities can be represented in texts, graphics, figures or designs. Material products are also implicated; tools and instruments which are imbibed with and crystallised by human intelligence. They are thinking tools. They have a hybrid character being both epistemic entities and physically manifested in analogue and digital artifacts (Paavola \& Hakkarainen, 2014).

The processes of «knowledge creation» are viable in educational environments thanks to the technological revolution that has occurred in collaborative learning in the last few decades. These technologies provide collaborative spaces for creation, sharing, and the development of «trialogical» objects.

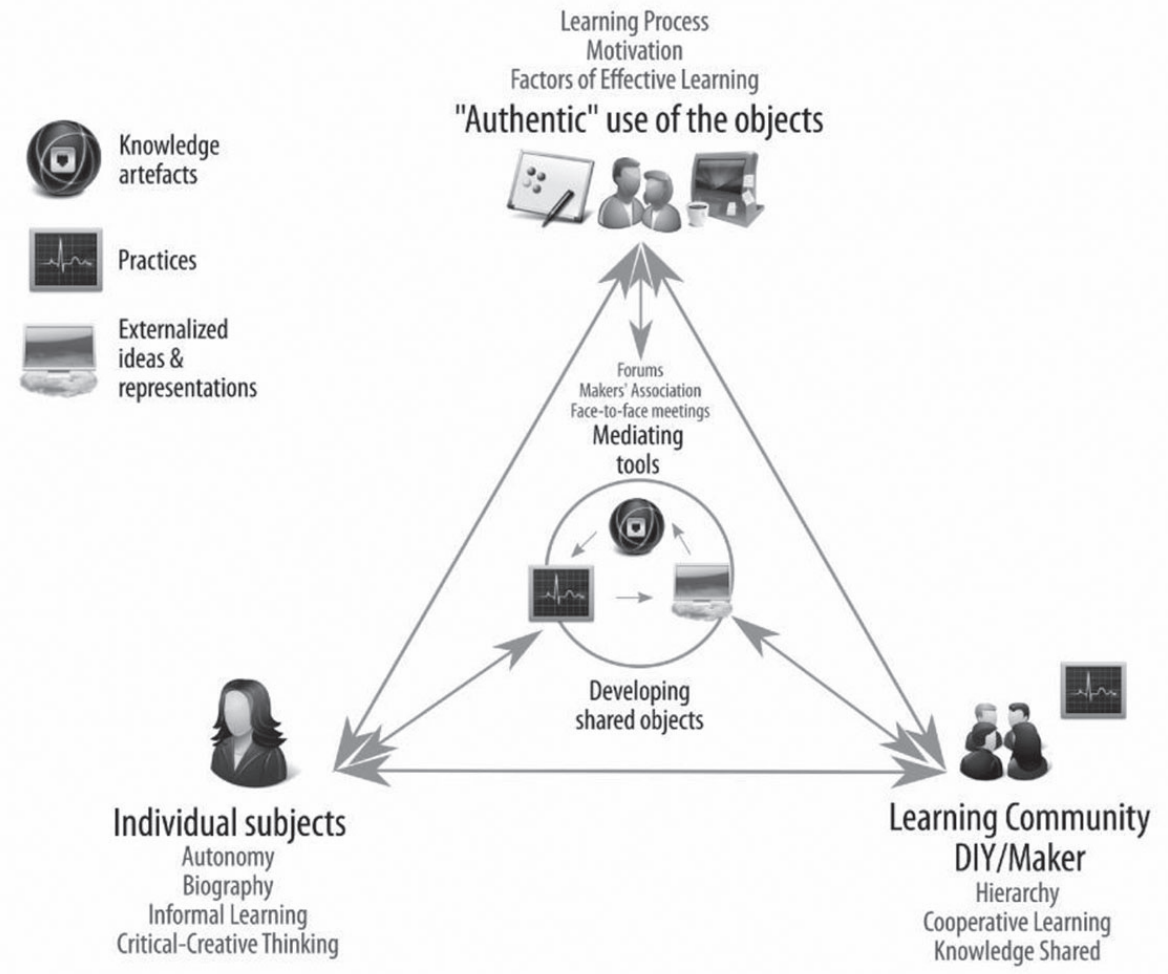

Figure 1. Trialogical Learning: Elements, Interaction and Products Source: Prepared by the author, based on Hakkarainen \& Paavola (2009). 
The basic characteristics of trialogical learning are the following (Paavola \& Hakkarainen, 2005):

- The creation of knowledge has its place via the development of shared knowledge objects (which can be conceptual or practical products) with different degrees of abstraction, solidity, and evolution.

- The process of knowledge creation is not linear. Instead, it is discontinuous, full of sudden barriers and obstacles. It includes tensions and contradictions which can present themselves as holes in the investigation.

- The processes of knowledge creation have their place amongst interactions between individual and collective activities.

- Inter-fertilisation of knowledge practices exists within educational, professional and investigative communities.

- Mediation technology exists; designed for the creation, construction, and sharing of knowledge in a collaborative way and on a long-term basis.

- Development through transformation and reflection: trialogical learning as a process of creating knowledge is developed via the interaction, and transformation between tacit knowledge, practices and conceptualisations.

\section{Maker movement}

A manifestation of these new learning ecologies is the «Maker Movement» denomination (Dougherty, 2012) which is defined as «a community of hobbyists, tinkerers, engineers, hackers and artists who creatively design and build projects for both playful and useful ends» (Martin, 2015, 30).

We can locate the «maker» movement within the Trialogical Learning Approach (Hatch, 2014; Kwon \& Lee, 2017; Collier \& Wayment, 2018). Maker networks have developed innovative processes of adult learning, knowledge construction, and knowledge sharing. These groups create their own alternative teaching and information dissemination models using innovative modalities (Hemphill \& Leskowitz, 2013). The maker movement has gone through three «waves» (Fox, 2014). The «Third Wave» resorts to the functionality of internet reading/writing, design/manufacture supported by digital technology, allowing anyone to invent, design, make and/or sell goods that they produce themselves. Through blogs, forums, and wikis, as well as social networks and video sharing services, makers can access specialized knowledge to increase efficiency. In universities, some initiatives have been developed for formal education such as «Fab labs» or «Makerspaces» (Halverson \& Sheridan, 2014; Fleischmann et al., 2016; Wong \& Partridge, 2016; Sánchez-Valero et al., 2017). Within obligatory education, the Maker movement has had an influence on the development of STEM knowledge areas (Schad \& Jones, 2020).

The question we pose with this investigation is the following: Is the Trialogical Learning Approach a theoretically valid focal point from which to analyse and comprehend the 
learning processes of a maker community? With the purpose of studying the explanatory validity of the Trialogical Learning Approach (TLA), the following investigative goals are put forward: (a) Identify in a «maker community» case study, different components of TLA: learning community, individual subjects, and authentic shared objects (products); and (b) Describe the learning processes of this «maker community» from the theoretical foundations of TLA.

\section{Methodology}

The current development of qualitative investigations in relation to learning processes and virtual environments as places of interaction and of communication, allows us to determine different focuses of qualitative methodology in concrete studies, along with observing the limitations and possibilities of such focal points. In our case, situating ourselves at the central axis of the investigation, we use an interpretative paradigm and case study methodology for all agents involved (Stake, 1995; Yin, 2009). This case shows a scene where a self-organised learning process has occurred. Learning is distributed and invisible (informal and trialogical learning), in the context of expanded education and found to be present in the interaction of contents, people, materials, and digital artifacts which are in the process of activating diverse mechanisms for attaining diverse objectives.

\section{Procedure}

This investigation uses a qualitative and case study approach (Stake, 1995), collecting data by conversational or narrative techniques and document analysis, taking a group of people in a digital forum as study subjects $(n=7.125)$. Candidates decide to implement self-learning processes to make a handcrafted product. In the forum, four different profiles are identified: Administrators, Moderators, Members $(\mathrm{n}=840)$, and Registered Users. The management team within the forum consists of two administrators and nine moderators. Each member and the registered user has a «range» defined by a system of badges according to the number of messages shared on the forum. The total number of messages at the time of the research amounted to 148,746, grouped in 13,133 topics. To carry out a content analysis of this forum, the themes with the largest number of messages were selected ( 28 themes, $\mathrm{n}=2,712$ messages).

\section{Planned data analysis}

Collection of case data, by incidental sampling, was carried out using several techniques: (1) In-depth narrative interview with key informants (3 members and one user) ${ }^{1}$.

${ }_{1}$ The data supporting the results and analyses presented in the paper can be found in https://doi. org/10.6084/m9.figshare.9794549.v1. 
(2) Non-participant observation (forum 2,712 messages) and (3) Documentary analysis (websites of the makers' community). Informed consent was obtained from the participants in the study. The procedure for analyzing the data obtained was carried out with NVivo 11 Plus software. Several sources of information were used for data triangulation, enabling us to offer a holistic and more credible reconstruction of reality. Classification of the data obtained made it possible to catalogue units covered by the same topic conceptually. The encoding was carried out independently by the authors and subsequently agreed upon. It constituted the specific operation, by which we have assigned to each unit, an indication of the category in which it is to be included.

The classification work began with in-depth interviews recorded on audio files and later transcribed into text format. After this categorization, the contents of messages in the forum were captured (NCapture extension by Nvivo 11 Plus). Qualitative analysis of transcriptions was as follows (Rodríguez, Gil and García, 1999): (1) Division of text into thematic units: (2) Identification of indications of a unit-theme (conversations, events, activities) using abbreviations. (3) Identification of text segments referring to the same theme. (4) Grouping data units to identify thematic components in order to build content categories. (5) The operational definition of categories and identification of subcategories. (6) Categorization and coding of selected texts and assignment of a code to each primary category. (7) Formulation of a categorical model and indicators (issues) which, after a data coding process, required several adjustments until a final model could be reached. It is presented below in the research results.

\section{Results}

The results are presented in the function of the three basic components of TLA: learning community, individual subjects, and authentic shared objects. The issues (nodes) that make up this case study are presented in Figure 2. Different aspects arise, which are relevant to the study of new learning ecologies, enabling us to understand the learning processes linked to the maker experience. 


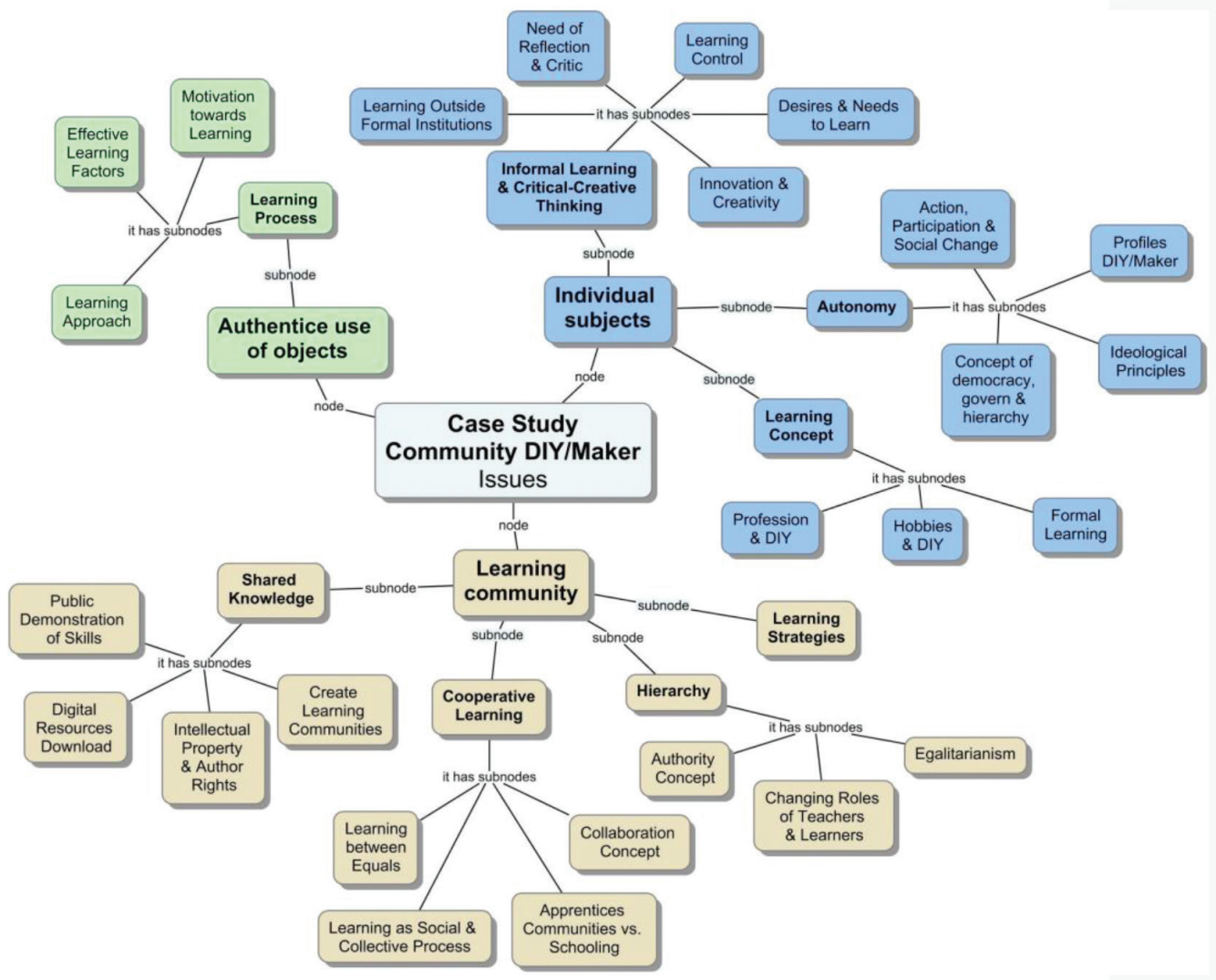

Figure 2. Map of Case Study Issues According to TLA

Source: Prepared by the author.

\section{Learning community}

\section{Learning strategies}

For makers, digital technologies are the perfect ally to satisfy learning needs, share knowledge and experience, become part of a practice community, and display results. Among the strategies used in the learning process, the following can be identified:

(a) Demonstration of processes and procedures: search and selection of digital resources, especially videos, that directly display specific modes of fabrication of the product, the construction of tools or machines linked to its manufacture or presentation by experts.

«I see a lot of multimedia content.»(EA_AAF).

«We look for information on the Internet, but we like to socialize [...] because you read it and you imagine it...but if you see it ... visual memory. Seeing it helps quite a lot. » (EA_PCH). 
(b) Explanation of processes and procedures: the maker's most highly valued and most commonly used resources are specialized forums. The quality of the forum depends on several factors: the active team of administrators and moderators, a careful organization of information, operation rules of the forum, tools for searching selected information or the frequency of participation and consequently, update of the forum on a daily basis.

«Before, when there were less of us and we were starting out, problems were basic. What we would consider to be serious problems today has changed. The most veteran participants do not enter into trivial debates. That is left for the newcomers, who sometimes look for solutions themselves. However, we have a 'super-master' in the group and [once] when a topic began to be discussed and each person began to give their opinion more or less; often imagining, going by impression, without any sort of evidence or proof, or anything of the sort....Suddenly, this colleague appeared whose nickname was "easy"...and he gave us a 'Pdf' with all the methods you could think of, for the issue we were discussing. He had "it" and he had tried everything....with the photos, with the trials, with the results, the pros, and the cons, and left everything with us.» (EA_AMJ).

(c) Checking and contrasting processes and procedures: information obtained is not only selected and stored, but is also put into action to check practical application. Replicating the processes of other makers is a necessary activity to incorporate alternative creations into the store of personal knowledge (or not). Moreover, contrasting processes are essential, testing one's final product against that of other makers so as to identify errors in one's own manufacturing process.

«I look for different pieces of information from several forums or different people and sometimes they are contradictory while others coincide. So what is the solution? You become practical and do it yourself. If it comes out well? Marvellous. If it comes out badly? ... Well, it will have to be repeated.» (EA_RGF).

(d) Identification of expert knowledge: as more information is acquired and selected, knowledge is put into practice. Progress takes on a spiral ascension which provides more precise criteria to discard new information found on the Internet or not.

«What you start to learn at the beginning is light years away from what we know now.» (EA_RGF).

(e) Specialized skills searching for information: experience in information enquiry on internet search engines and databases, enables makers to develop specific skills for: a more rigorous selection of search terms, a capacity to organize information with greater precision and enhanced structure. This facilitates subsequent retrieval of information and leads to a faster evaluation of the quality of the sources obtained. Additionally, technology itself favours this process with automatically stored information (e.g. browser history, favourites, and cookies). The makers' association promotes this skill, organizing 
contests, setting challenges for the fabrication of a specific type of product. Such trials encourage participants to search and investigate the manufacturing processes necessary to construct the specified product on their own, locating precise and valid sources to meet the challenge.

«I have also realized that the more professional you are when searching, the more professional the pages you obtain from your search will be.» (EA_RGF).

(f) Creation of specialized workspaces: the layout of work environments where makers put knowledge into practice and apply ideas and innovations, is a crucial factor in carrying out projects successfully.

«To have a small water analysis laboratory and things like that, [...] I need special water characteristics and [...] with several very basic lab tools it is possible to do quite a lot of things...which I have planned to do as well.» (EA_RGF).

(g) Serendipity: The search for information on the Internet, although clearly focused on a specific goal, very often due to its nature, leads to broader information, data or ideas, considered relevant by virtue of opening up unexpected possibilities. Current knowledge is improved or expanded and unexplored procedures are discovered. Once a quality source of information has been identified, the specifics of an individual search might become less important. Here, the attitude of the makers is observed to be one of openness towards new knowledge, that was not explicitly looked for.

«When you search for certain information and start reading, you often find answers to other doubts you had and which were not what you were looking for...so you are saving time. [...] in this process, in which you are looking for an answer to a simple query...often other questions are simultaneously resolved although you weren't looking to solve them at that moment...you find them by chance.»(EA_RGF).

(h) A proactive attitude regarding knowledge: it was seen that makers do not merely want to become technicians applying the recipes of others uncritically. An attitude focused on the direct satisfaction of a need without any personal effort is frowned upon by community makers. Thus, before asking for help, it is necessary to prove that one has previously tried to find solutions to a problem for oneself. To ask for and receive, it is expected that one demonstrates an interest in acquiring more knowledge.

«I don't ask, I always search. The question you are going to ask has often been asked already. Search. For this reason, I often don't ask. I am beginning to realize that the moment you go to the search engine of the forum with the question that you have in mind..the question appears there because everyone [...] started practically from scratch...so all the questions are there.» (EA_RGF).

(i) More efficient and effective reading comprehension: given the enormous amount of information needed to be read and assimilated, makers must develop fast reading and rapid comprehension skills enabling the digestion of more data in less time. 
(j) Knowledge through dialogue: in contrast to a representation of knowledge as a pre-packaged and pre-structured product, taking into account the supposed interests of the recipient, makers are seen to highly value the chance to access knowledge through questions and answers in the forums. This learning model is considered to offer information that is more relevant, more direct, and easier to understand.

«Each person has a specific problem and confusion arises when people begin to appear giving different answers. As a result of seemingly contradictory responses, a debate begins and people start to contribute their knowledge, information, sources and so on....and well, things become very active and quite a creative learning process ensues, doesn't it?» (EA_AMJ).

\section{Cooperative learning}

One of the primary sources of information for makers are forums, which require a basic level of education for active participation. A small group of people is identified, who moderate the forum and welcome people who join in and answer questions rapidly. A proactive attitude is essential to take advantage of the knowledge shared in the forum. A question or request for help should be accompanied by evidence given by the user that he is informed, has some knowledge or has carried out a test on the procedure. Makers in the group must read the "Frequently Asked Questions," research in topics of interest or continue previous threads before asking a question in the forum which may have already been answered. Even perhaps looking for information outside of the forum would be encouraged, before requesting assistance that is to be found elsewhere on the internet. The forum is a space for the social exchange of learning that has clear objectives and a mode of operation that is strictly controlled to avoid conflicts caused by incorrect use or controversial content in messages. Furthermore, forums are organized thematically so that conversations are correctly focused and can be followed without distraction.

«There's an impressive variety and above all, you encounter very positive attitudes, very focused on transmitting knowledge and sharing it.» (ACOP_AMJ).

\section{Knowledge sharing}

The association of this makers group is seen to understand knowledge as something that should be open and that sources shared should be legal, a matter dealt with in regulations of the ACCE Forum. This viewpoint is shared by other makers and to all extent, it is explicitly stated. Through dissemination of information and shared open knowledge, one intention included in the goals of the makers association is to promote a «maker culture».

«I think so. I think that people, in this respect, share knowledge. In fact, there was a debate among us when the association was created about whether certain things on the website should be public or private. We reached the conclusion that [some content] should be placed in a private area for members, where it would be possible to deal with particular matters related to 
the association. [...] Later the articles were made public because it was considered to be of no use having them only for members, when others were interested in the subject matter. Indeed, one of the purposes of the association is precisely that; disseminating and promoting [...]»(FAE_AMJ).

\section{Hierarchy}

Within this group of makers, an equal treatment among all users is observed and leaders do not behave in a hierarchical manner according to status within the group. In fact, leaders are the most active and try to answer most of the questions asked. A critical attitude towards knowledge is maintained by the leadership, rather than a passive acceptance of content supplied by other members of the group.

«Those that are more active are viewed to have quite a lot more fluid knowledge and they refocus quickly $[. .$.$] I mean that they are people who consistently$ exert a great deal of information and interest in answering any type of question.»(MODIG_RGF).

\section{Authentic use of objects}

\section{Effective learning factors}

Makers explain different variables or factors which might be used to outline a concept of "effective learning": (1) Demonstration of the applicability of learning: for makers, the teaching process should be focused on facilitating the learner's acquisition of a clear vision of potential applications of knowledge. (2) Re-establishing the balance between theoretical and practical content: for makers, access to conceptual or factual content arises from a need for resolution in practical situations and is therefore linked to specific information requirements. (3) Expansion and facilitation of access to different sources of information: one of the main contributions valued by makers in digital technologies, is access to a broad scope of information. (4) Generation of learning activities with an increasing degree of complexity: the ideal learning model identified in this community of makers, begins as an activity designed to be fruitful and gradually becoming more complex and thereby requiring new theoretical knowledge. (5) Transformation of the learning process into a «jigsaw puzzle»: more than a linear process, learning is articulated around a collection of elements that should be linked, tried, evaluated, and finally incorporated into knowledge. (6) Carrying out of tests, trials and experiments: each maker adopts the role of a «scientist» who using a method: controls variables, replicates processes, records data, and evaluates results. Makers enjoy tests because they offer an experience considered to provide deep learning in the process of also having to confront errors. (7) Information synthesis, and direct expression styles: communication of knowledge must be done in such a manner that conceptual data or procedures are expressed in the simplest way possible to favour initial comprehension and later the complexity of information may be gradually raised. 
«Researcher: What is the role of trial and error in your process? Maker: Vital. It is fundamental. Here, we mostly learn by trial and error, you try things. Above all, you also discover that as in all fields of knowledge, answers in books are often false. It was taken for granted because you read it.» (FAE_AMJ).

\section{Learning process}

The learning process that defines this group contains the following basic elements: theoretical knowledge is meaningful as long as it is focused on real-life application and learning should be local and contextualized for it to be of interest. Learning is seen to be a result-orientated, active and pragmatic process; «learning by doing» enables an error to have a point of comparison and subsequently overcome. The memorization of information not linked to a specific function is viewed as ineffective. Learning is not regarded as compatible with the need to accumulate a series of data pre-determined by a teacher and then evaluated in a reproductive examination. It is not necessary for learning processes to be homogeneous; it is necessary for the learner to have autonomy.

«Researcher: Fundamentally, we can conclude that for you it is thought best in any learning process, to learn by doing ... Maker: Yes. Researcher: ... learning by doing or in a way that is closely linked to the activity and with the application of what is known. Maker: Yes, that's the case for me. For me it's 'super important' because at the end of the day, you discover how to use content... and the content is there provided... but the capacity to apply it - you are not going to find that on the Internet or anywhere else.» (CA_RGF).

This approach to learning is highly pragmatic, closely linked to the satisfaction of specific everyday life needs. It relates to personal interests and what is considered essential to know by the individual. The selection of content for an "official" curriculum is questioned as is an excessive emphasis on data, facts and concepts isolated from all contextualization and application. Manual activity is another essential characteristic of the learning style determined by this makers' group. Learning is always accompanied by a physical and analogical activity that enables one to create, build, develop and produce. At the same time a cognitive activity is present, perhaps digital (supported by technology) that guides the learning process and contributes to a learning foundation where possible errors can be explained and hypothetical solutions found. It is advantageous for makers to evaluate their own learning results because criteria is not externally established. Judgment on progress and advances in knowledge can be carried out personally, without social pressure or outside prejudice. In this way, self-criticism is valued as a principle element in the self-evaluation of results. When confronted with error and failure, it is considered that there is always a second chance; the possibility of redoing and recreating what has failed. This is something that is not possible with the same flexibility in formal education.

«I don't have to give explanations to anybody. [...]. Nobody evaluates me. I evaluate myself and criticize myself, you know? If I'm wrong, I can fix it tomorrow.» (CA_RGF). 
«The capacity for self-criticism is very important if you want to progress - Not like the saying that goes: "don't try to solve the same problem a thousand times" but instead you have to learn from your mistakes.» (CA_AMJ).

\section{Individual subjects}

\section{Learning concept}

Through consideration of the prior educational experience of makers, it is possible to extract a student profile that demonstrates: an interest in continuous learning, curiosity to apply knowledge and a capacity to analyse, reflect and criticize the curricular content found in the formal education system.

«For me, learning is a proactive process on the part of the learner. [...] in these types of groups, the most important aspect of this learning is the learner's attitude; people come because they are interested in the topic and are selfmotivated.»(CA_AMJ).

Going through compulsory levels of education requires an effort on the part of the student to adapt to a context that might not satisfy the student's interests and might not align with the student's vision of the teaching-learning process. Constant and excessive theorization and the lack of knowledge application and a merely reproductive model can leave a learner's hunger insatiable. The interests of makers are varied but they all have something in common: they require a creative aspect and autonomous and manipulative learning skills. It is considered that choosing a maker philosophy is more a question of attitude and personality than something related to the particular profession of the individual.

«I am a person for whom all learning must have an application. [...] Theory is all very well because you need a knowledge base, but everything must have an application.»(CA_RGF).

\section{Autonomy}

Current pathways for information access, with the possibilities offered by digital technologies, are transforming how we think about what knowledge is and how it should be disseminated. Free access to information is perceived as a right for all citizens who wish to learn. The perceived social value, which formal education systems have had up until now, is changing. Consequently, a monopoly on knowledge has been lost and now one can access all sorts of the information according to one's interests, from one's own home. This creates a space of freedom, most highly desired by makers, who need information to give form to their own learning process.

«Now with this, I mean for example that I don't go to an academy to learn. I don't go to school to learn. I don't go to a company giving training courses to learn. I learn at home for free. In such a manner [...] a teacher does not 
take me along a pre-established route or a way in which he considers more appropriate.» (PID_RGF).

\section{Informal learning and critical-creative thought.}

Makers are search engines. Enquirers that need to satisfy their curiosity and are attracted by the challenge of building things and making products. Many of these needs cannot be satisfied with the formal education system. Digital technologies give access to information and create relationships between people with similar interests. Identification of experts, accessible through the networks, enables the maker to solidify the foundations of their learning. The internet broadens the limits of knowledge and democratizes access to information, the dissemination of ideas, and the construction of knowledge. The validity of the knowledge received is questioned when what has been learnt are mere concepts and data, devoid of application in real situations.

Consequently, autonomy within self-learning is a characteristic that identifies makers and sets them apart as rigorous, observant and reflexive learners. Errors provide a source of information that must be analysed to improve processes in the future. Makers are self-critical; they are not frustrated by a setback or an undesired result. What could initially be taken as learning a series of specific, well-articulated and well-founded techniques to achieve the product is progressively modified until it includes innovations and disruptions to the initial intention. Along the way, entirely different challenges present themselves, arising from the learning process itself.

«It is highly spontaneous. Content depends a lot on people's personal needs. Therefore, information and learning become more and more specific.» (AIPC_AMJ).

«Researcher: You need others to value your work or your products, don't you? Maker: Yes, because [...] firstly, one is not entirely critical when making judgments alone but above all one is limited in the knowledge one has to detect problems or evaluate the quality itself. The fact is that there are other people, who have more experience than you. Alternatively, more simply, [you benefit] when different people try products and see what they think, give their opinion and detect some errors that you haven't detected, or some variations of this kind, that you have been unable to detect.» (CNAP_AMJ).

\section{Conclusions}

The case study enables us to detect the presence of three elements that comprise the «trialogical learning» process. Firstly, we observe a learning community composed of a numerous group of makers who are committed to the development of their specific interest, which is making a handcrafted product, with different degrees of cognitive and 
social involvement. This community is formally articulated as a legitimate association, but it operates with a significant degree of flexibility and autonomy thanks to the effective use of digital technologies for communication. Secondly, individual group members are characterized as belonging to the «maker culture», displaying their preferences for open knowledge, experiential, and active learning (learning by doing), a positive attitude to information sharing, competence development based on trial and error and activities focused on the construction-manufacturing of products. In short, makers are co-builders of knowledge in a continuous and ever-more complex and specialized process. In third place, we identify within this makers group, an «authentic» use of epistemic objects. Whether it be ideas (e.g. conception of the product), designs (e.g., recipes), analogical prototypes (e.g., machines, utensils) or digital products (e.g., software), the experiences (e.g., manufacturing process) and their tangible results (final product), all have a practical and applied function, always focused on the ultimate goal of the group. These ideas are related to Väljataga's approach (2016) which ensures that trialogical learning principles contribute to the understanding of current learning focuses which are being developed in virtual platforms. It is interesting to observe how students in a formal context, end up constructing their own settings for virtual learning, selecting resources and tools which are more closely related to their needs and objectives.

In addition, it has been possible to identify components within trialogical learning interactions. Measurement tools, which are digital technologies for communication and the exchange of information (e.g., the web, forums), are used very effectively and are essential for the formation of a learning community. This can be looked at together with the development of epistemic objects, shared between members of the makers' group: exhaustive description of processes, detailed explanation of manufacturing techniques, decision-making motivations, guidelines for searching useful information or software applications to facilitate manufacturing processes.

Finally, the existence of the third component of trialogical learning is identified: the «products» (authentic use of objects). Primarily we are referring to knowledge artifacts, which evolve within the makers' group to satisfy the learning needs of individual members, from the beginner to the expert. We can highlight the flexibility within this learning community to adapt to the level of competence of individuals and at the same time, the personal commitment to be proactive in the acquisition of the skills necessary to become a producer. Furthermore, practice forms the base of all learning in the makers' group and is characterized by being shared, thought about, continuously improved, and evaluated. In the end, what makes up the educational and cultural heritage of this makers' group are ideas and an externalized representation of knowledge, recorded and accessible by digital means and materialized in texts, images, and videos. These identifications coincide with the study done by Lakkala, Ilomäky \& Paavola (2012) in which they evaluate pedagogical practices within the framework of TLA. It is ensured that knowledge artifacts enable course participants to externalize their ideas, generate awareness, and learn to work as 
part of a team. It can be concluded that the pedagogical design based on TLA, provides heuristic clues for understanding learning processes in open communities and for designing educational spaces with this specific focus in mind. With a similar approach, Sansone, Cesareni, Ligorio, Bortolotti \& Buglass (2019) propose the TLA viewpoint and its pedagogical principles for the design of didactic exercises in higher education, based on team-work and the creation of useful artifacts.

In conclusion, the TLA has proven itself to be an adequate model for describing and interpreting underlying learning processes found in a maker community. Previous investigations had indeed evidenced their utility in the analysis of formal education contexts. However, it is true that this study is limited to a specific case and requires further investigation which applies the TLA to other practices falling within the scope of informal education and including analysis of long-term impacts, so as to identify with greater precision, dimensions which emerge and are maintained over time. In our case, the study offers a starting point for analysis of the principles of the TLA in such contexts and also its potential application in formal education processes where effective learning environments might be designed, based on new learning ecologies.

\section{Funding}

This work was supported by grants for the execution of investigative activities, technological development, the dissemination and transference of knowledge by the investigation groups working at the Universidad de Extremadura. Consejería de Economía, Ciencia y Agenda Digital. Junta de Extremadura (Spain). Ref. GR18071. National R\&D\&I Plan. Ministerio de Ciencia, Innovación y Universidades (Spain) Ref. RTI2018-097144-B-I00.

\section{References}

Anderson, J. R. (1983). The architecture of cognition. Mahwah, N.J.: Lawrence Erlbaum Associates. Ausubel, D. P., Novak, J. D., \& Hanesian, H. (1978). Educational psychology: A cognitive view (2nd ed.). New York: Holt, Rinehart and Winston.

Bereiter, C. (2002). Education and mind in the knowledge age. Mahwah, N. J.: L. Erlbaum Associates.

Brown, J. S., Collins, A., \& Duguid, P. (1989). Situated cognition and the culture of learning. Educational Researcher, 18(1), 32-42.

Bruner, J. S., Goodnow, J. J., \& Austin, G. A. (1956). A study of thinking. Oxford: Wiley.

Collier, A. F., \& Wayment, H. A. (2018). Psychological benefits of the "maker" or do-it-yourself movement in young adults: A pathway towards subjective well-being. Journal of Happiness Studies, 19(4), 1217-1239. doi: 10.1007/s10902-017-9866-x 
Dougherty, D. (2012). The maker movement. Innovations: Technology, Governance, Globalization, 7(3), 11-14. doi: 10.1162/INOV_a_00135

Engeström, Y., \& Sannino, A. (2010). Studies of expansive learning: Foundations, findings and future challenges. Educational Research Review, 5(1), 1-24. doi: 10.1016/j.edurev.2009.12.002 Engeström, Y. (2015). Learning by expanding: An activity-theoretical approach to developmental research (2nd ed.). New York, NY: Cambridge University Press.

Fleischmann, K., Hielscher, S., \& Merritt, T. (2016). Making things in Fab Labs: A case study on sustainability and co-creation. Digital Creativity, 27(2), 113-131. doi: 10.1080/14626268.2015.1135809

Fox, S. (2014). Third wave Do-It-Yourself (DIY): Potential for presumption, innovation, and entrepreneurship by local populations in regions without industrial manufacturing infrastructure. Technology in Society, 39, 18-30. doi: 10.1016/j.techsoc.2014.07.001

Fuller, S. (1991). Social epistemology. Bloomington, I.N.: Indiana University Press.

Hakkarainen, K. (2009). A knowledge-practice perspective on technology-mediated learning. International Journal of Computer-Supported Collaborative Learning, 4(2), 213-231. doi: 10.1007/s11412-009-9064-x

Hakkarainen, K., \& Paavola, S. (2009). Toward a trialogical approach to learning. In B. Schwarz, T. Dreyfus, \& R. Hershkowitz (Eds.), Transformation of knowledge through classroom interaction (pp. 65-80). New York: Routledge.

Halverson, E. R., \& Sheridan, K. (2014). The maker movement in education. Harvard Educational Review, 84(4), 495-504. doi: 10.17763/haer.84.4.34j1g68140382063

Hemphill, D., \& Leskowitz, S. (2013). DIY activists: Communities of practice, cultural dialogism, and radical knowledge sharing. Adult Education Quarterly, 63(1), 57-77. doi: $10.1177 / 0741713612442803$

Hatch, M. (2014). The maker movement manifesto: Rules for innovation in the new world of crafters, hackers, and tinkerers. New York: McGraw-Hill Education.

Kwon, B. R., \& Lee, J. (2017). What makes a maker: The motivation for the maker movement in ICT. Information Technology for Development, 23(2), 318-335. doi: 10.1080/02681102.2016.1238816 Lakkala, M., Ilomäki, L., Paavola, S., Kosonen, K., \& Muukkonen, H. (2012). Using trialogical design principles to assess pedagogical practices in two higher education courses. In A. Moen, A. I. Mørch, \& S. Paavola (Eds.), Collaborative knowledge creation: Practices, tools, concepts (pp. 141-161). Rotterdam: SensePublishers. doi: 10.1007/978-94-6209-004-0

Lave, J., \& Wenger, E. (1991). Situated learning: Legitimate peripheral participation. Cambridge: Cambridge University Press. doi: 10.1017/CBO9780511815355

Malins, J., Gray, C., \& Aggelos, L. (2015). Trialogical learning. A new framework for learning through the creative relationship between emerging technologies and multiple participants. In D. Bihanic (Ed.), Empowering users through design (pp. 177-191). Cham: Springer International Publishing. doi: 10.1007/978-3-319-13018-7_10

Martin, L. (2015). The promise of the maker movement for education. Journal of Pre-College Engineering Education Research (J-PEER), 5(1), 30-39. doi: 10.7771/2157-9288.1099 
Miller, G. A. (1956). The magical number seven, plus or minus two: Some limits on our capacity for processing information. Psychological Review, 63(2), 81-97. doi: 10.1037/h0043158

Muukkonen, H., \& Lakkala, M. (2009). Exploring metaskills of knowledge-creating inquiry in higher education. International Journal of Computer-Supported Collaborative Learning, 4(2), 187-211. doi: 10.1007/s11412-009-9063-y

Nonaka, I., \& Takeuchi, H. (1995). The knowledge-creating company: How Japanese companies create the dynamics of innovation. New York: Oxford University Press.

Paavola, S., \& Hakkarainen, K. (2014). Trialogical approach for knowledge creation. In S. C. Tan, H. J. So, \& J. Yeo (Eds.), Knowledge creation in education (pp. 53-73). Singapore: Springer. doi: 10.1007/978-981-287-047-6_4

Paavola, S., Lakkala, M., Muukkonen, H., Kosonen, K., \& Karlgren, K. (2011). The roles and uses of design principles for developing the trialogical approach on learning. Research in Learning Technology, 19(3), 233-246. doi: 10.3402/rlt.v19i3.17112

Paavola, S., Lipponen, L., \& Hakkarainen, K. (2004). Models of innovative knowledge communities and three metaphors of learning. Review of Educational Research, 74(4), 557-576. doi: 10.3102/00346543074004557

Rodríguez Gómez, G., García Jiménez, E., \& Gil Flores, J. (2005). Metodología de la investigación cualitativa [Methodology of qualitative research]. Málaga: Aljibe.

Sánchez-Valero, J.-A., Arrazola-Carballo, J., \& Calderón-Garrido, D. (2017). The DIY Lab project (Do It Yourself in education: Expanding digital competence to foster student agency and collaborative learning). Cultura y Educación, 29(4), 871-878. doi: 10.1080/11356405.2017.1383637

Sansone, N., Cesareni, D., Ligorio, M. B., Bortolotti, I., \& Buglass, S. L. (2019). Developing knowledge work skills in a university course. Research Papers in Education, 35(1), 23-42. doi: $10.1080 / 02671522.2019 .1677754$

Schad, M., \& Jones, W. M. (2020). The maker movement and education: a systematic review of the literature. Journal of Research on Technology in Education, 52(1), 65-78. doi: 10.1080/15391523.2019.1688739

Stake, R. E. (1995). The art of case study research. Thousand Oaks: Sage Publications.

Väljataga, T. (2016). Students' learning environments for distance international collaboration. In Y. Li, M. Chang, M. Kravcik, E. Popescu, R. Huang, Kinshuk, \& N.-S. Chen (Eds.), State-ofthe-art and future directions of smart learning (pp. 211-220). Singapore: Springer.

Wong, A., \& Partridge, H. (2016). Making as learning: Maker's spaces in universities. Australian Academic \& Research Libraries, 47(3), 143-159. doi: 10.1080/00048623.2016.1228163

Yin, R. K. (2009). Case study research: Design and methods. Los Angeles: Sage Publications. 


\title{
Triloginis mokymasis kaip kūrèjų bendruomenès teorinè skaitmeninè ekosistema: atvejo analizè
}

\author{
Jesús Valverde-Berrocoso일 María Rosa Fernández-Sánchez ${ }^{2}$
}

1 Edukologijos mokslų katedra, Mokytojų rengimo fakultetas, Estremadūros universitetas, Universiteto prospektas s/n10003-Kaseresas, Ispanija, jevabe@unex.es

2 Edukologijos mokslų katedra, Mokytojų rengimo fakultetas, Estremadūros universitetas, Universiteto prospektas s/n 10003- Kaseresas, Ispanija, rofersan@unex.es

\section{Santrauka}

Skaitmeninès technologijos keičia mokymo(si) procesus, todèl būtina suprasti naujas mokymosi ekologijas technologinėse ekosistemose. Metaforų apie mokymąsi, kaip apie monologo-dialogo procesą, nepakanka naujiems, skaitmeninių technologijų keičiamiems švietimo reiškiniams, tokiems kaip kūrèjų bendruomenès, paaiškinti. Šiame straipsnyje mokymosi bendruomenès nagrinejamos iš „triloginio mokymosi“ perspektyvos, remiantis tokia triada: sudedamosios dalys, tarpusavio sąveika ir rezultatas. Naudota kiekybinio tyrimo ir atvejo analizės metodologija. Duomenys surinkti naudojant giluminius interviu, stebejimą nedalyvaujant ir dokumentų analizę. Straipsnyje analizuojamos temos apima mokymosi sampratą; efektyvaus mokymosi procesą; strategijas ir faktorius; mokymąsi bendradarbiaujant; kritinį-kūrybinị mąstymą; savarankiškumą; dalijimąsi žiniomis ir jų hierarchiją. Taigi atvejo analizè leido įrodyti, kad egzistuoja visi „triloginio mokymosi“ komponentai, ir tai suteikia galimybę šias žinias pritaikyti formaliojo mokymosi transformacijai. Skaitmeninès ir informacinès technologijos (internetas, forumai) yra naudojamos labai efektyviai ir yra būtinos kuriant besimokančią bendruomenę.

Esminiai žodžiai: triloginio mokymosi prieiga, kūrèju judèjimas, pasidaryk pats (angl. Do It Yourself (DIY)), atvejo analizé, praktikos bendruomene. 